\title{
Pulp fruit added to culture medium for in vitro orchid development
}

\section{Polpa de frutos adicionada ao meio de cultivo no crescimento in vitro de orquídea}

\author{
Gilberto Rostirolla Batista de Souza ${ }^{1 *}$; Alessandro Borini Lone ${ }^{2}$; \\ Ricardo Tadeu de Faria ${ }^{3}$; Karen Sinéia de Oliveira ${ }^{4}$
}

\begin{abstract}
As an additive in in vitro culture media, fruits have a great potential for facilitating economical orchid production because of lower technology requirements and the ease of obtaining raw materials to formulate culture media. We studied the in vitro growth of Cattleya bicolor Lindl. grown in a simplified culture medium supplemented with different kinds of fruit pulp. The experimental design was completely randomised, with eight seedlings per replication and ten replications per treatment, for a total of 80 seedlings per treatment. The culture medium was made using $150 \mathrm{~g} \mathrm{~L}^{-1}$ of pulp (without peel or seed) from the following fruits: ripe Santa Cruz tomatoes (Solanum lycopersicum L.), dwarf bananas (Musa cavendishii L.) of intermediate ripeness, light green chayote (Sechium edule (Jacq.) Sw), ripe papaya (Carica papaya L.) or green coconut (Cocos nucifera L.). The treatment control was MS 50 $\%$. The treatments and the control were kept in a growth chamber for seven months before evaluating seedling survival percentage, shoot height, number of leaves, rooting percentage, root number, root length and dry masses of shoot and roots. The highest percentages of seedling survival were obtained using MS $50 \%$, banana and coconut medium. The seedling survival and rooting percentages illustrate that it is possible to emphasise the culture medium MS 50\% and the culture medium supplemented with coconut on the most traditional culture medium with banana or tomato pulp. For the in vitro development of Cattleya bicolor Lindl., a simplified culture medium supplemented with coconut pulp is the most suitable for use as an alternative to MS 50\%. A simplified culture medium supplemented with papaya pulp is not recommended for the in vitro development of Cattleya bicolor Lindl.
\end{abstract}

Key words: Alternative culture medium, Cattleya bicolor Lindl., conservation, subculture, coconut

\section{Resumo}

Os frutos apresentam potencial para serem utilizados na elaboração de meios de cultivo para facilitar a produção de orquídeas em pequenas propriedades, contribuindo para a rentabilidade do cultivo. Objetivou-se com este trabalho analisar o crescimento in vitro de Cattleya bicolor Lindl. cultivada em meio de cultivo simplificado e suplementado com polpa de diferentes frutos. O delineamento experimental foi inteiramente casualizado, com oito plântulas por repetição e 10 repetições por tratamento, totalizando 80 mudas por tratamento. Os tratamentos foram o incremento de $150 \mathrm{~g} \mathrm{~L}-1$ de polpa sem casca ou semente de Solanum lycopersicum L. maduro, Musa cavendishii L. entre verde e maduro, Sechium edule (Jacq.) Sw., Carica papaya L. maduro ou Cocos nucifera L. verde e o tratamento controle foi o $M S 50 \%$. Os frascos foram mantidos em câmara de crescimento por sete

\footnotetext{
${ }^{1}$ Discente de Doutorado em Agronomia, Produção Vegetal, Universidade Estadual Paulista “Júlio de Mesquita Filho", UNESP/ FCAV, Jaboticabal, SP. E-mail: gilberto.rostirolla@gmail.com

${ }^{2}$ Discente de Doutorado em Agronomia, Universidade Estadual de Londrina, UEL, Londrina, PR. E-mail: alone_bio@yahoo.com. br

${ }^{3}$ Eng $^{\circ}$ Agr ${ }^{\circ}$, Prof. Dr. Associado do Dept ${ }^{\circ}$ de Agronomia,UEL, Londrina, PR. E-mail: faria@uel.br

${ }^{4}$ Discente de graduação em Agronomia, UEL, Londrina, PR. E-mail: karynkimberly@hotmail.com

* Author for correspondence
} 
meses antes das avaliações de porcentagem de sobrevivência das plântulas, comprimento da parte aérea $(\mathrm{cm})$, número de folhas, porcentagem de enraizamento, número de raízes, comprimento das raízes e massa seca da parte aérea e das raízes. As maiores porcentagens de sobrevivência das plântulas foram para os meios de cultura MS $50 \%$, MS suplementado com banana e coco. Contudo, com os resultados de porcentagem de sobrevivência e porcentagem de enraizamento obtidos, é possível ressaltar os meios de cultivo MS $50 \%$ e o suplementado com coco sobre os meios de cultivo mais tradicionais contendo polpas de banana ou tomate. O meio de cultivo simplificado suplementado com polpa de coco é o mais adequado como alternativa ao meio MS com metade dos macronutrientes para o crescimento in vitro de C. bicolor. O meio de cultura simplificado suplementado com polpa de mamão não é recomendado para o desenvolvimento in vitro de Cattleya bicolor Lindl.

Palavras-chave: Meio de cultivo alternativo, Cattleya bicolor Lindl., conservação, subcultivo, coco

Cattleya bicolor Lindl. is a species endemic to Brazil that can be found in the Cerrado (a tropical savannah ecoregion) and the Atlantic Forest (BARROS et al., 2010). The predatory collection of this orchid has contributed significantly to the reduction of its population (BATISTA; BIANCHETTI; PELLIZZARO, 2005). Though not on the Official List of Endangered Species of Brazilian Flora (MMA, 2008), it was included in the IUCN Red List of Endangered Species of Flora of Minas Gerais state (MENINI NETO et al., 2007).

Unemoto et al. (2007) and Stancato, Abreu and Furlani (2008) have demonstrated that increasing or decreasing certain components of an in vitro culture medium can promote the satisfactory growth of orchids. Various components, including macro and micronutrients, vitamins and growth regulators, can be reduced, eliminated or replaced with fruit pulp or other plant parts. In addition to reducing costs, simplified culture media do not use ammonium nitrate or potassium nitrate, which are elements used in MS medium (MURASHIGE; SKOOG, 1962) and whose sales are controlled by the Ministry of Defense (UNEMOTO et al., 2007).

Numerous studies have been conducted to investigate in vitro cultures containing various additives, includingbanana, tomato fruits and coconut water (BRAHM; GOMES; BOSENBECKER, 2006; STANCATO; ABREU; FURLANI, 2008, VIEIRA et al., 2009). Given the wide variety of fruit suitable for use as in vitro additives, the easy access to them in Brazil and the possible benefits that they can bring to the in vitro culture of orchids, it is appropriate to consider the effects of fruit pulp on the in vitro growth of $C$. bicolor. Our study examined a simplified culture medium supplemented with the pulp of Solanum lycopersicum L., Musa cavendishii L., Sechium edule (Jacq.) Sw), Carica papaya L. or Cocos nucifera L., in comparison with MS culture medium.

The experiment was conducted at the Laboratory of Plant Science at Londrina, Paraná state, Brazil. The orchid species used was Cattleya bicolor Lindl.

Seedlings with an average height of $1.23 \pm 0.24$ $\mathrm{cm}$ without roots were obtained by culturing seeds in vitro on MS medium (MURASHIGE; SKOOG, 1962). These seedlings were then cultured in a modified culture medium, with eight seedlings per flask and ten flasks per treatment. The flasks were kept in a growth room maintained at a temperature of $26 \pm 2{ }^{\circ} \mathrm{C}$, with $27 \mu \mathrm{mol} \mathrm{m} \mathrm{m}^{-2}$ of light intensity and a photoperiod of 16 hours.

The culture medium was made using 150 $\mathrm{g} \mathrm{L}^{-1}$ of pulp (without peel or seed) from the following fruits: ripe Santa Cruz tomatoes (Solanum lycopersicum L.), dwarf bananas (Musa cavendishii L.) of intermediate ripeness, light green chayote (Sechium edule (Jacq.) Sw), ripe papaya (Carica papaya L.) or green coconut (Cocos nucifera L.). The pulp was mixed with the culture medium with the aid of a blender. All treatments were prepared using a simplified culture medium containing $2 \mathrm{~g}$ $\mathrm{L}^{-1}$ of $\mathrm{N}, \mathrm{P}_{2} \mathrm{O}_{5}, \mathrm{~K}_{2} \mathrm{O}$ (10-10-10) fertiliser, $100 \mathrm{~mL}$ $\mathrm{L}^{-1}$ of fresh coconut water (green fruits removed), 
$20 \mathrm{~g} \mathrm{~L}^{-1}$ sugar (sucrose PA) and $7.0 \mathrm{~g} \mathrm{~L}^{-1}$ agar. Seedling growth for each treatment was compared to seedlings grown in half-strength MS (MS $50 \%$ ) with no added vitamins, supplemented with $1.0 \mathrm{~g}$ $\mathrm{L}^{-1}$ of activated charcoal, $30.0 \mathrm{~g} \mathrm{~L}^{-1}$ sucrose PA and $7.0 \mathrm{~g} \mathrm{~L}^{-1}$ agar (Kolb do Brasil).

The $\mathrm{pH}$ of each medium was adjusted to 6.3 , and all media was autoclaved for 25 minutes at $125^{\circ} \mathrm{C}$ and $1 \mathrm{~atm}$.

After seven months, the percentage of seedling survival (\% SS), the shoot height (ASH), the number of leaves (NL), the rooting percentage ( $\% \mathrm{R})$, the number of roots $(\mathrm{RN})$, the root length (LR) and the dry masses of shoots (SDM) and roots (RDM) were evaluated. The $\mathrm{pH}$ of each culture medium was taken with a digital pen type $\mathrm{pH}$ meter. The ASH and LR were measured with a ruler, and the SDM and RDM were measured using an accurate analytical balance.
The experimental design was completely randomised, with eight seedlings per replication and ten replications per treatment, for a total of 80 seedlings per treatment. Data were subjected to an analysis of variance and were evaluated by the Scott Knott test at a 5\% significance level. Data regarding the percentage of seedling survival $(\% \mathrm{SS})$, the number of leaves (NL), the root number $(\mathrm{RN})$, the average length of roots (LR) and the dry mass of shoots (SDM) were processed $\sqrt{ }(\mathrm{X}+0.5)$; the root dry mass $(\mathrm{RDM})$ data were processed $\sqrt{ }(\mathrm{X}+0.05)$ only for the statistical effect and are presented in the table without alteration.

Seedling survival data showed that $100 \%$ of seedlings grown on MS 50\% survived through the end of the experiment. Ninety-five per cent of seedlings grown in culture media containing banana and coconut survived, whereas seedlings grown in media containing chayote, tomato or papaya had a poor survival rate (Table 1).

Table 1. Presents the components of seedling development of C. bicolor: Percentage of seedling survival (\%SS), average shoot height $(\mathrm{ASH})$, number of leaves $(\mathrm{NL})$, rooting percentage $(\% \mathrm{R})$, root number $(\mathrm{RN})$ and average length of roots (LR) after seven months in vitro culture.

\begin{tabular}{|c|c|c|c|c|c|c|c|c|c|c|c|}
\hline Treatment & $\% \mathrm{SS}^{1}$ & & ASH (cm) & $\mathrm{NL}^{1}$ & & $\% \mathrm{R}$ & & $\mathrm{RN}^{12}$ & & $\operatorname{LR}(\mathrm{cm})$ & \\
\hline MS $1 / 2$ macro & 100,00 & $a^{3}$ & 2,21 a & 4,65 & $\mathrm{a}$ & 100,00 & $\mathrm{a}$ & 4,95 & $\mathrm{a}$ & 1,29 & $\mathrm{a}$ \\
\hline Banana & 95,00 & $\mathrm{a}$ & $1,29 \mathrm{sb}$ & 2,80 & $\mathrm{a}$ & 57,50 & $\mathrm{~b}$ & 4,28 & $\mathrm{a}$ & 0,76 & $\mathrm{a}$ \\
\hline Coconut & 95,00 & $\mathrm{a}$ & 1,77 a & 3,25 & $\mathrm{a}$ & 80,00 & $\mathrm{a}$ & 3,15 & $\mathrm{~b}$ & 0,93 & $\mathrm{a}$ \\
\hline Chayote & 75,00 & $\mathrm{~b}$ & $1,44 \quad b$ & 2,74 & $\mathrm{a}$ & 50,00 & $\mathrm{~b}$ & 2,13 & $\mathrm{c}$ & 1,02 & $\mathrm{a}$ \\
\hline Tomato & 77,50 & $\mathrm{~b}$ & 1,72 a & 3,38 & $\mathrm{a}$ & 55,00 & $\mathrm{~b}$ & 3,08 & $\mathrm{~b}$ & 0,74 & $\mathrm{a}$ \\
\hline Papaya & 65,00 & $\mathrm{~b}$ & $1,16 \quad b$ & 1,42 & $\mathrm{~b}$ & 17,50 & $\mathrm{c}$ & 1,13 & $\mathrm{~d}$ & 0,50 & $\mathrm{a}$ \\
\hline CV $(\%)$ & 8,19 & & 20,50 & 13,16 & & 22,40 & & 11,28 & & 12,42 & \\
\hline
\end{tabular}

${ }^{1}$ Data processed $\sqrt{ }(\mathrm{X}+0.5)$ only for the statistical effect. Data presented in the table without transformation.

${ }^{2}$ Average number of roots in relation to the number of seedlings that have roots.

${ }^{3}$ Means followed by same letter in columns do not differ by the Scott Knott test $(p<0.05)$.

Source: Elaboration of the authors.

The results of our study confirmed the findings of Brahm, Gomes and Bosenbecker (2006), who added potato, banana, papaya and tomato pulp to culture media to grow Schomburgkia orchids; these researchers conducted experiments using one, two and four kinds of fruit pulp in the same medium. The best results occurred when only one kind of pulp per medium was used; banana pulp was the 
most successful, followed by papaya and tomato. However, the medium containing tomato did not result in a satisfactory survival rate, and the addition of papaya pulp did not result in good growth of $C$. bicolor seedlings (Table 1).

In a study that analysed media containing different concentrations of coconut milk and banana, Vieira et al. (2009) found that the best results for the production of the orchid $C$. labiata $\mathrm{x} C$. forbest was a modified MS 50\% medium containing $1 \mathrm{~g} \mathrm{~L}^{-1}$ of activated charcoal and supplemented with $100 \mathrm{~g} \mathrm{~L}^{-1}$ banana. However, in our study, C. bicolor developed in MS 50\% and the simple media containing banana or coconut, but each fruit in different ways and at a concentration of $150 \mathrm{~g} \mathrm{~L}^{-1}$ (Table 1)

In disagreement with our results for the variable survival percentage of seedlings grown in media with papaya pulp, Assakawa et al. (2009) concluded that Knudson "C" media with ripe papaya pulp showed little mortality for seedlings of the hybrid C. warneri $\mathrm{T}$. Moore Alba x L. purpurata Lindl. var. Venosa. The difference in results may be due to several factors, including the concentration of the fruit pulp used or the difference in orchid species selected for study.

Media containing coconut and tomato produced seedlings with shoot heights (ASH) similar to those grown in MS $50 \%$ medium. These were also superior to media containing banana, papaya and chayote (Table 1).

Stancato, Abreu and Furlani (2008), among others, have demonstrated that culture media containing banana pulp are beneficial for the growth of roots and leaves. Our study showed that media containing coconut pulp or supplemented with tomato pulp were beneficial for the shoot height of C. bicolor; neither produced results significantly different from the control (Table 1).
Data collected from each treatment for the number of leaves (NL) showed no significant differences between media containing MS $50 \%$, bananas, chayote, tomatoes and coconut. However, all showed a higher number of leaves when compared with the treatment containing papaya. Araújo et al. (2006), testing different concentrations of banana pulp, found that increasing concentrations of banana pulp resulted in the development of a smaller number of leaves (Table 1).

The percentage of rooting $(\% \mathrm{R})$ data showed that the MS $50 \%$ and coconut media both performed better than the other treatments. The presence of good root development reflects when the vessel is transferred to the vase in plant quality and hence better quality of flowering (Table 1).

The highest number of roots was produced in MS $50 \%$ and banana media, followed by media containing coconut and tomato. No significant differences among treatments were observed for root length (RL) (Table 1).

Araújo et al. (2006), when studying the in vitro development of $C$. loddgesii 'Great' x C. loddgesii 'Alba', found that the largest number of roots was produced in a culture medium containing $60 \mathrm{~g} \mathrm{~L}^{-1}$ of banana pulp and that the greatest root length was produced in a culture containing $100 \mathrm{~g} \mathrm{~L}^{-1}$. Similarly, Vieira et al. (2009) observed that culture medium containing banana pulp and coconut water showed better root development.

Media containing chayote and papaya had lower SDM averages compared with other media. Ferreira et al. (2010) reported that culture media supplemented with banana pulp promoted higher seedling weight in Baptistonia pubes seedlings (Table 2). 
Table 2. Presents the dry mass of shoot (SDM) and the root dry mass (RDM) of plantlets and the pH values from the different culture media at the end of the experiment.

\begin{tabular}{|c|c|c|c|}
\hline Treatment & $\operatorname{SDM}(g)^{1}$ & $\operatorname{RDM}(g)^{2}$ & pH end \\
\hline MS $1 / 2$ macro & $0,05240 a^{3}$ & $0,05720 \quad \mathrm{a}$ & $3,15 \mathrm{~b}$ \\
\hline Banana & 0,03883 a & $0,03400 \quad \mathrm{a}$ & 4,38 a \\
\hline Coconut & 0,02485 a & $0,01855 \quad b$ & 4,62 a \\
\hline Chayote & $0,01235 \mathrm{~b}$ & $0,00720 \quad b$ & 4,81 a \\
\hline Tomato & $0,04473 \quad$ a & $0,01915 \quad b$ & $5,00 \quad \mathrm{a}$ \\
\hline Papaya & $0,00475 \quad b$ & $0,00011 \quad b$ & 4,28 a \\
\hline CV $(\%)$ & 24,94 & 29,44 & 10,18 \\
\hline
\end{tabular}

${ }^{1}$ Data processed $\sqrt{ }(X+0.5)$ only for the statistical effect. Data presented in the table without transformation.

${ }^{2}$ Data processed $\sqrt{ }(X+0.05)$ only for the statistical effect. Data presented in the table without transformation.

${ }^{3}$ Means followed by same letter in columns do not differ by the Scott Knott test $(p<0.05)$.

Source: Elaboration of the authors.

The RDM was higher for C. bicolor in MS 50 $\%$ and banana media. Both were superior to the others, with no significant differences between them. Stancato, Abreu and Furlani (2008) found that media containing banana pulp had the highest dry matter content in the roots of Laelia longipes, Miltonia spectabilis and Laelia tenebrosa. Among the kinds of fruit pulp tested, our study showed similar results for the production of $C$. bicolor; media containing coconut and tomato also resulted in high dry matter content. Also verified that three species of orchids grown on MS $50 \%$ medium accumulated the least dry matter content of root and shoot; the opposite result occurred in our study, in which MS 50\% demonstrated the highest values of all variables (Table 2).

When compared to the baseline, the $\mathrm{pH}$ at the end of the experiment was more acidic for all treatments. Even presenting the biggest change, the MS $50 \%$ medium (control) demonstrated the best results in all criteria with the treatment coconut (Table 2).

It is possible to increase nutrient availability to seedlings by adjusting the $\mathrm{pH}$ of the medium. (PASQUAL et al., 2002). Rosique, Rosique and
Chein (1976) reported that plants, through root exudation, can acidify the substrate in which they grow to facilitate the absorption of some nutrients.

As an additive in in vitro culture media, fruits have a great potential for facilitating economical orchid production because of lower technology requirements and the ease of obtaining raw materials to formulate culture media. This methodology promotes sustainable development, helps generate employment and aids in the conservation of biodiversity (VYAS et al., 2009). The seedling survival and rooting percentages illustrate that it is possible to emphasise the culture medium MS 50\% and the culture medium supplemented with coconut on the most traditional culture medium with banana or tomato pulp.

For the in vitro development of Cattleya bicolor Lindl., a simplified culture medium supplemented with coconut pulp is the most suitable for use as an alternative to MS 50\%

A simplified culture medium supplemented with papaya pulp is not recommended for the in vitro development of Cattleya bicolor Lindl. 


\section{References}

ARAÚJO, A. G. de; PASQUAL, M.; VILLA, F.; COSTA, F. C. Coconut water and banana pulp for in vitro growth of orchid plantlets. Revista Ceres, Viçosa, v. 53, n. 310, p. 608-613, 2006.

ASSAKAWA, R. H.; FARIA, S. L. de; ZONETTI, P. da C.; BIDO, G. de S. In vitro culture of Cattleya warneri T. Moore Alba x Laelia purpurata Lindl. var. Venosa in nutrient medium supplemented with green or ripe papaya pulp for seed germination and development of orchids. Maringá: International Meeting of Scientific Production, 2009. (Cesumar, 6).

BARROS, F. de; VINHOS, F.; RODRIGUES, V. T.; BARBERENA, F. F. V. A.; FRAGA, C. N. Orchidaceae in list of species of brazilian flora. Jardim Botânico do Rio de Janeiro. 2010. Available at: <http://floradobrasil. jbrj.gov.br/2010>. Accessed at: 20 feb. 2011.

BATISTA, J. A. N.; BIANCHETTI, L. de B.; PELLIZZARO, K. F. Orchidaceae of the reserva ecológica do Guará, Distrito Federal, Brazil. Acta Botânica Brasílica, São Paulo, v. 19, n. 2, p. 221-232, 2005.

BRAHM, R. U.; GOMES, J. C. C.; BOSENBECKER, V. K. Alternative culture medium for growth and development of orchids in vitro. Revista Brasileira de Agroecologia, Cruz Alta, v. 1, n. 1, p. 1623-1626, 2006.

FERREIRA, A. W. C.; LIMA, M. I. S.; FARIA, R. T. de; RIBEIRO, J. P. N.; CASALI, C. A. Propagation in vitro of Baptistonia pubes (Lindl.) Chiron \& V. P. Castro (Oncidium pubes Lindl. - Orchidaceae). Acta Botânica Brasílica, São Paulo, v. 24, n. 3, p. 636-639, 2010.

MENINI NETO, L.; ALVES, R. J. V.; BARROS, F. de; FORZZA, R. C. Orchidaceae of Ibitipoca State Park, Minas Gerais State, Brazil. Acta Botânica Brasílica, São Paulo, v. 21, n. 3, p. 687-696, 2007.
MINISTÉRIO DO MEIO AMBIENTE - MMA. Official list of endangered species of brazilian flora. 2008. Available at: <http://www.mma.gov.br/estruturas/ ascom_boletins/_arquivos/83_19092008034949.pdf>. Accessed at: 15 feb. 2011.

MURASHIGE, T.; SKOOG, F. A revised medium for rapid growth and bioassays with tabacco tissue cultures. Physiologia Plantarum, Sweden, v. 15, p. 95-497, 1962.

PASQUAL, M.; FINOTTI, D. R.; DUTRA, L. F.; CHAGAS, E. A.; RIBEIRO, L. de O. In vitro culture of 'Poncã' mandarin immature embryos: $\mathrm{pH} \times$ agar concentration. Revista Brasileira de Agrociência, Pelotas, v. 8, n 3, p. 199-202, 2002.

ROSIQUE, I. R.; ROSIQUE, I.; CHEIN, L. A. Botany beddings. São Paulo: FTT Press, 1976.

STANCATO, G. C.; ABREU, M. F.; FURLANI, A. M. C. The pulps of fruits in growth of epiphytic orchids. Bragantia, Campinas, v. 67, n. 1, p. 51-57, 2008.

UNEMOTO, L. K.; FARIA, R. T.; VIEIRA, A. O. S.; DALIO, R. J. D. In vitro propagation of Brazilian orchids on a simplified culture medium. Revista Brasileira de Agrociência, Pelotas, v. 13, n. 2, p. 267-269, 2007.

VIEIRA, J. G. Z.; UNEMOTO, L. K.; YAMAKAMI, J. K.; NAGASHIMA, G. T.; FARIA, R. T. de; AGUIAR, R. S. de. In vitro propagation and aclimatization of Cattleya Lindl. (Orchidaceae) using banana pulp and coconut water. Cientifica, Jaboticabal, v. 37, n. 1, p. 48-52, 2009.

VYAS, S.; GUHA, S.; BHATTACHARYA, M.; USHA RAO, I. Rapid regeneration of plants of Dendrobium lituiflorum Lindl. (Orchidaceae) by using banana extract. Scientia Horticulturae, Amsterdam, v. 121, n. 1, 2, p. 3237, 2009. 